\title{
California's Rangeland Water Quality Management Plan: An Update
}

\section{By Melvin George, Stephanie Larson-Praplan, John Harper, David Lewis, and Michael Lennox}

I n late 1989, California's Range Management Advisory Committee, made up of livestock industry and public members, identified water quality as a priority issue. In 1990, California's range livestock industry began to develop a program of voluntary compliance with the Federal Clean Water Act, federal and state coastal zone regulations, and California's Porter-Cologne Act, which provides for regulation of water quality by the State Water Resources Control Board (SWRCB) and nine Regional Water Quality Control Boards. ${ }^{1}$ This livestock industry initiative led to development of the California Rangeland Water Quality Management Plan (CRWQMP) for nonfederal rangelands, which was approved by the SWRCB in $1995 .^{2}$ The objectives of the CRWQMP were to conduct management activities that would prevent sediment, nutrients, pathogens, and water temperature from exceeding prescribed standards established by California's Regional Water Quality Control Boards (RWQCB). The CRWQMP proposed that nonfederal rangeland owners and managers voluntarily develop a management strategy at the ranch and watershed level that would 1) determine impairment to beneficial uses of water bodies in the ranch's watershed and 2) assess the causes of impairments. The CRWQMP, developed in collaboration with regulatory agencies, state advisory committees, private consultants, the US Department of Agriculture Natural Resources Conservation Service (NRCS), and University of California Cooperative Extension (UCCE), provided for development and implementation of ranch water quality plans that address these two objectives on a voluntary basis.

\section{Ranch Water Quality Planning Short Course} In 1994, UCCE and NRCS began to consider education programs that would support plan development by landowners at a time when they were concerned that state regulations would impact private property rights. ${ }^{3}$ We decided to implement a nonpoint source (NPS) pollution training program that addressed the technical aspects of NPS pollution while helping ranchers complete water quality plans. These plans focused on NPS assessment, development of water quality protection objectives, implementation of practices, and short- and long-term monitoring.

In 1995 and 1996, prototypes of the Ranch Water Quality Management Planning (RWQMP) short course were conducted by UCCE and NRCS in Mendocino, Sonoma, Marin, San Luis Obispo, and Plumas Counties. The target audience for the short course was the owners and managers of nonfederal, primarily privately owned rangelands used for livestock production. The curriculum developed during the prototype short courses was standardized for course uniformity in September 1997. From 1997 to 2004 more than 70 RWQMP short courses were conducted in California.

The objective of this 10- to 15 -hour short course was to help ranchers voluntarily meet the objectives of the CRWQMP. During the RWQMP short course rangeland owners 1) learned to determine water quality impairments in the ranch's hydrologic unit/basin from state and regional assessments, 2) learned to document existing ranch practices that protect water quality, 3) conducted a water quality self-assessment of the ranch, 4) reviewed rangeland best management practices that address nonpoint pollution sources identified during the self-assessment, 5) documented existing practices that protect water quality, 6) selected potential management practices that could improve water quality protection on the ranch, and 7) learned to monitor NPSs of pollution and practice effectiveness. Ranch Water Quality Plans were developed during the short course using a computer-based "fill in the blanks" plan that could be augmented with additional information such as maps, soils surveys, and other reports. The short course curricula can be reviewed and downloaded from the following Web address: http://californiarangeland.ucdavis.edu. This Web site can also be reached via http://rangelandswest.org.

During the first meeting of the RWQMP short course (Fig. 1) we wanted to help ranchers 1) understand how grazing and ranching activities could be a source of 


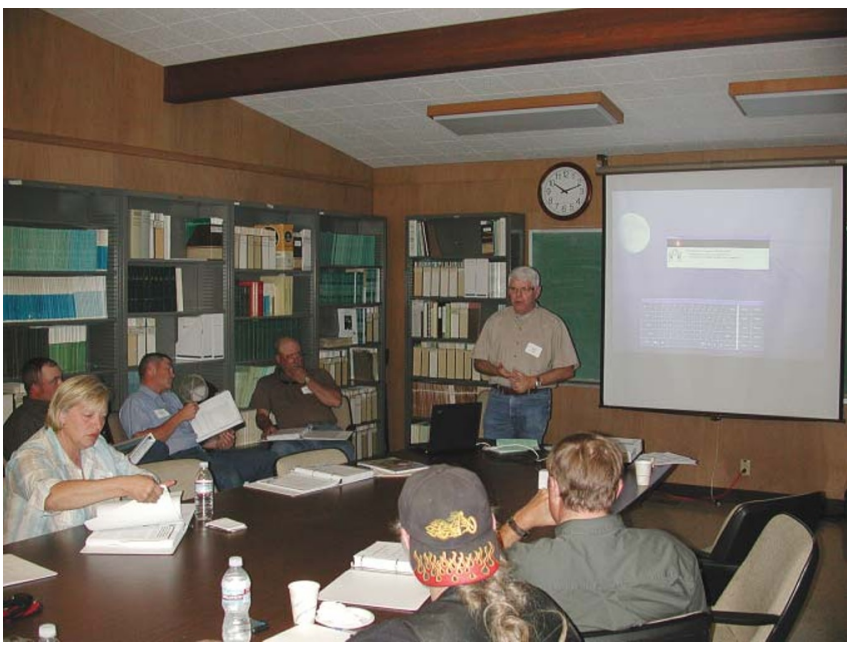

Figure 1. Ranch Water Quality Management Planning short course meeting.

pollution, 2) become knowledgeable about water quality impairments in the watershed or basin in which their ranch was located, and 3) have a basic understanding of state (California's Porter-Cologne Act) and federal (Clean Water Act and Coastal Zone Management Act) water quality regulations. We used visual media to help ranchers visualize sources of sediment, nutrients, pathogens, and increased surface water temperature. We then reviewed the beneficial uses and the NPS pollution assessments of water bodies in the basins where course participants had ranches. We reviewed the 303(d) list of impaired water bodies required by the Clean Water Act, ${ }^{1}$ and we reviewed the total maximum daily load (TMDL) priority list for those basins. Once the ranchers were familiar with state and basin assessments that may affect their property and watersheds, we had the ranchers complete an NPS self-assessment checklist. The checklist asks the ranchers to identify sediment, nutrient, pathogen, and thermal pollution sources and streambank/ riparian conditions on their ranch.

In California the SWRCB has responsibility for developing water quality standards that protect beneficial uses of rivers, streams, lakes, and estuaries. Beneficial uses include drinking water, cold water fisheries, industrial water supply, recreation, and agricultural uses. Once standards are established, the state monitors water quality and reviews available data and information to determine if these standards are being met and water is protected. Section 303(d) of the federal Clean Water $\mathrm{Act}^{1}$ requires each state to develop a list of water bodies that do not meet standards and to submit this list to the U.S. Environmental Protection Agency every two years. The "303(d) list" provides a way to identify and prioritize water quality problems. The list also serves as a guide for developing and implementing watershed pollution reduction plans to achieve water quality standards and protect beneficial uses.

The TMDL is the amount of a particular pollutant that can be delivered to a particular stream, lake, estuary, or other water body without violating state water quality standards. Section 303(d) of the federal Clean Water Act requires states to develop TMDLs for impaired water bodies. Once a TMDL is established, responsibility for reducing pollution among both point sources (pipes) and diffuse sources is assigned. Diffuse "sources" include, but are not limited to, runoff (urban, agricultural, forestry, etc.), leaking underground storage tanks, unconfined aquifers, septic systems, stream channel alteration, and damage to a riparian area. There are five steps in producing a TMDL: 1 ) involve stakeholders, 2) assess the water body, 3) develop point and NPS allocations, 4) develop an implementation plan, and 5) amend the Basin Plan. Before a TMDL is enforceable it must be incorporated into the appropriate Basin Plan in accordance with state law. If TMDLs are not incorporated into Basin Plans, they have no legal standing under state law and cannot be enforced by RWQCBs.

The second meeting of the short course focused on ranch and rangeland practices that protect water quality and ranch water quality goals and measurable objectives. Using visual media we reviewed ranch and range management practices (best management practices) that protect water quality. We used terminology and practice numbers (Table 1) from the USDA NRCS Field Office Technical Guide. ${ }^{4}$ We reviewed widely used livestock distribution practices such as fencing and water development and other practices including herding, supplement placement, and trail development. Practices that reduce erosion, nutrient and pathogen loading, and streambank/riparian damage were emphasized. Because it is important for ranchers to take credit for their good management, we had the ranchers complete a checklist of water quality protection practices that they already had in place on the ranch. They then reviewed their water quality assessment checklist from the previous meeting and began to consider practices that might further reduce pollution sources identified on the assessment checklist. They were then ready to draft ranch water quality objectives that linked pollution sources they had identified to practices that could reduce pollution from these sources. Finally the ranchers were introduced to monitoring pollution sources on their property and in their watershed, and they began to develop a monitoring plan for the ranch. Measurable objectives, such as increasing riparian canopy cover or maintaining adequate residual dry matter, ${ }^{5}$ stated in their plans facilitated selection of appropriate monitoring practices.

The third meeting was devoted to ranch mapping, resource inventory, and estimating carrying capacity. USDA NRCS provided maps for each ranch, and overlays of boundaries and fences were developed during and after class. The final meeting was a field monitoring meeting where ranchers learned to 1) use ranch records and historic photos for monitoring, 2) set up photo monitoring points, 3) measure residual dry matter and stubble height, 4) conduct a sediment source inventory, and 5) adopt any other methods appropriate for the location (Fig. 2). Because sediment is the most prevalent pollutant on rangelands and is the target of several coastal TMDLs, ${ }^{6}$ 


\section{Table 1. List of management practices that pro- tect water quality using terminology and practice numbers from the USDA NRCS Field Office Technical Guide ${ }^{4}$}

\begin{tabular}{|l|}
\hline Grazing management practices \\
\hline Prescribed grazing (528a) \\
\hline Use exclusion (472) \\
\hline Structural range improvements \\
\hline Access roads (560) \\
\hline Fencing (382) \\
\hline Grade stabilization (410) \\
\hline Pipelines (516) \\
\hline Ponds (378) \\
\hline Sediment basins (350) \\
\hline Spring development (574) \\
\hline Stock trails or walkways (575) \\
\hline Streambank protection (580) \\
\hline Troughs and tanks (614) \\
\hline Landslide treatments (453) \\
\hline Wells (642) \\
\hline Stream crossings (interim) \\
\hline Land treatments \\
\hline Brush management (314) \\
\hline Prescribed burning (334) \\
\hline Critical area planting (342) \\
\hline Range seeding (550) \\
\hline Grazing land mechanical treatments (548) \\
\hline Stream corridor improvement (204) \\
\hline Wildlife wetland habitat management (644) \\
\hline Woodland development or restoration wildlife-upland \\
habitat management (645) \\
\hline Livestock management practices \\
\hline Livestock parasite control \\
\hline Supplemental feeding and salting \\
\hline
\end{tabular}

a sediment inventory and monitoring procedure was added to the course in $2001 .^{7}$

\section{Short Course Impact}

The short course impact included the following:

- From 1995 to 2007, more than 70 short courses were conducted in 35 counties with representatives from more than 1000 ranches and other nonfederal lands attending.

- More than 2 million acres of nonfederal rangeland were voluntarily placed under water quality plans from 1997 to 2007.

- According to a survey in $2002,{ }^{8}$ the majority of the course participants completed a plan and implemented water

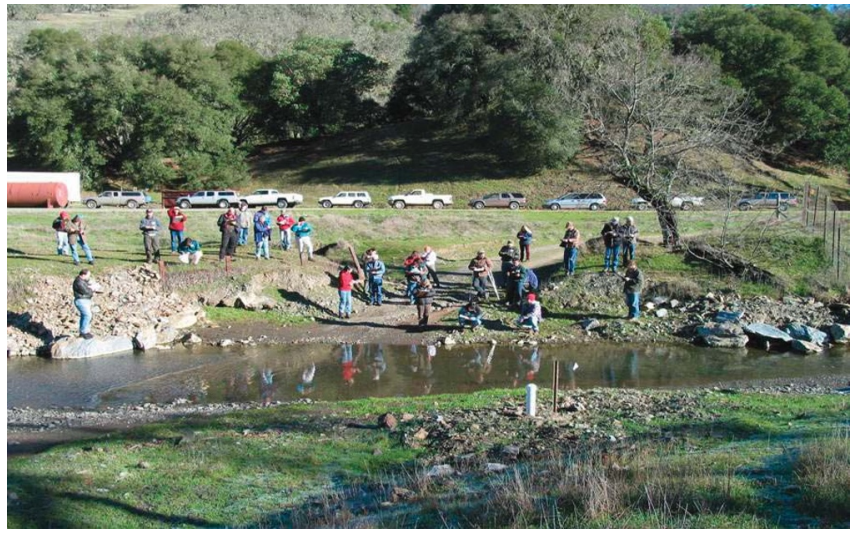

Figure 2. Field monitoring meeting in Sonoma County, California.

quality protection practices during and following the short course.

- Landowners implemented watershed groups to collectively address NPS pollution.

- Course participants applied to USDA cost share programs such as the Environmental Quality Incentive Program.

- The University of California hired a Rangeland Watershed Cooperative Extension Specialist.

- The short course served as a model for the Central Coast Farm Water Quality Program conducted by UCCE.

\section{Rangelands Regulated}

In 2004, the SWRCB adopted policies for regulating NPS pollution. ${ }^{1}$ These policies affect landowners and agricultural producers, including range livestock operations. This new policy replaced the voluntary, education-supported program with regulatory programs, such as implementation of TMDL requirements for NPS discharges from agricultural lands, including grazing land. Although the compliance with water quality regulations is no longer voluntary, science-based information and education programs regarding rangelands, grazing, and water quality are still needed at the local level as TMDLs are developed and implemented on local watersheds and river basins.

In California the SWRCB uses three tools to obtain compliance with NPS regulations. The first is to obtain a Waste Discharge Requirements (WDR) permit from the RWQCB with specific criteria, conditions, and limits that describe how waste discharge from specific land management can be allowed. The WDR requires submittal of a report of waste discharge, annual fees, and approval by the RWQCB. The second tool is to waive WDRs. A waiver may be allowed following a formal hearing by the RWQCB if the waiver is consistent with state law. Waivers are conditional, with specific directives and requirements intended to reduce NPS discharge and impacts from permitted activities. Activities waived by RWQCBs may be exempt from filing a report of waste discharge and from annual fee requirements. The third way is through "Basin Plan Prohibitions." This provides for restrictions on pollutant discharges contained 


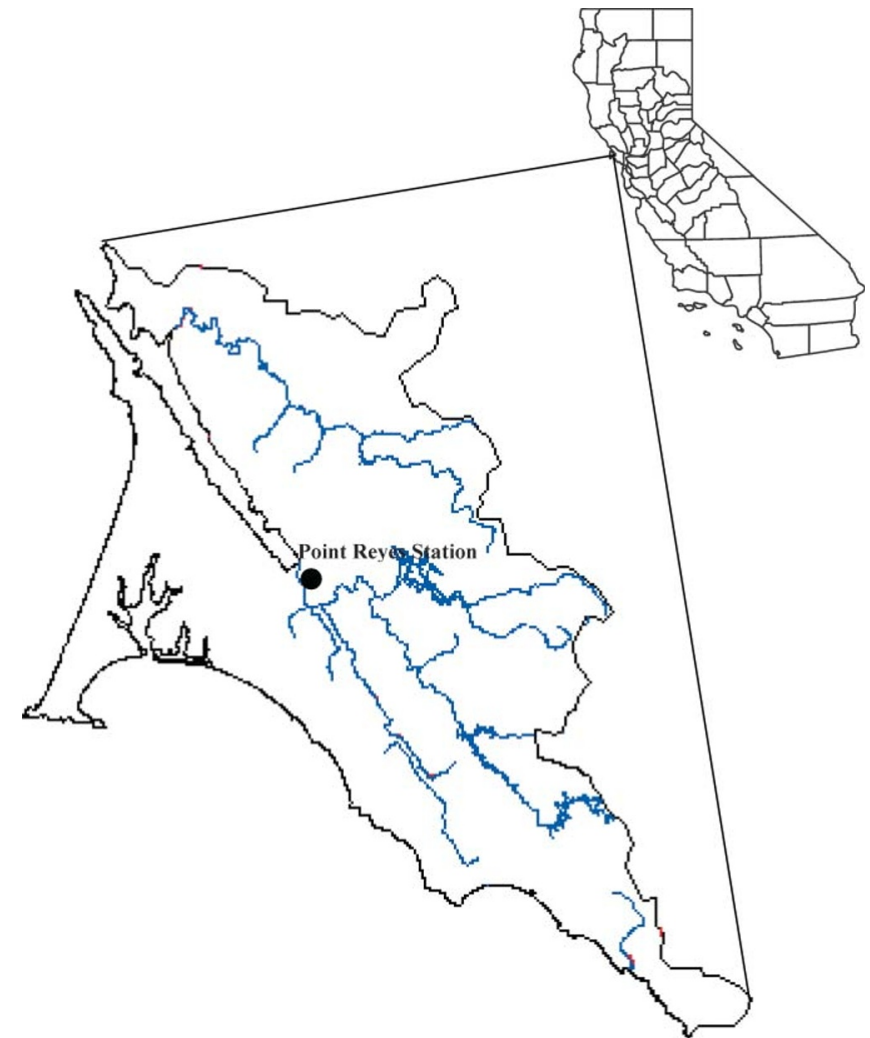

Figure 3. Map of Tomales Bay Watershed, 39 miles north of San Francisco, California.

within a basin plan rather than permits or waivers. This regulatory tool is used when discharges occur without a permit or waiver and provides a mechanism for immediate enforcement action to control a discharge. Some watershed groups and agricultural producers have chosen the waiver program to comply with NPS regulations. The grazing land owners and operators of the Tomales Bay Watershed were the first to comply with state water quality regulations by complying with the state's Conditional Grazing Operations Waiver program.

\section{Tomales Bay Watershed}

The Tomales Bay Watershed (Figs. 3 and 4) is about 255 square miles, an area 20 times the size of the bay. The bay, sitting atop the San Andreas Fault just north of San Francisco, is 12 miles long and only about 1 mile wide. The Tomales Bay waters are part of the Gulf of the Farallones National Marine Sanctuary. Eighty percent of the watershed is used for agriculture, primarily for grazing dairy and beef cattle.

The watershed supplies water, provides recreational opportunities, and supports dairy and beef ranching, farming, commercial fishing, and oyster production. The Tomales Bay Watershed is home to rich wildlife communities, including nearly 470 species of birds. Coho salmon (Oncorbynchus kisutch), steelhead trout (Oncorhynchus mykiss), and red-legged frogs (Rana draytonii) are important examples of threatened

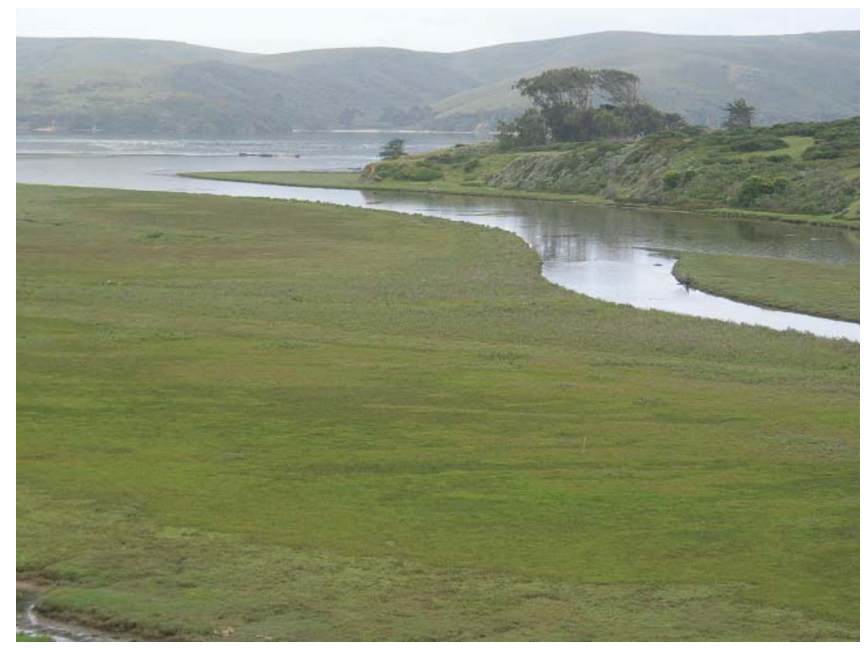

Figure 4. Tomales Bay Watershed.

and endangered species that rely on habitats in this watershed. Of the wild Coho salmon remaining along the central California coast from Humboldt to Santa Cruz Counties, nearly 20 percent of the population spawns in Lagunitas and Olema Creeks that flow into Tomales Bay.

In September 2005, the San Francisco Bay RWQCB approved the pathogen TMDL for the Tomales Bay Watershed. The RWQCB is also pursuing TMDLs for mercury, sediment, and nutrients. The pathogen TMDL calls for over 18 implementation actions including those applied to grazing lands, which make up 55\% of the watershed. The Marin Resource Conservation District (RCD) is assisting agricultural producers to comply with TMDL requirements by working with landowners to implement projects for improving water quality.

A significant step in the implementation of the TMDL is the requirement of grazing land owners and operators to comply with the Conditional Grazing Operations Waiver program. The Tomales Bay Watershed was the first to develop a Conditional Grazing Operations Waiver program in the state. Prior to this there had been waivers for livestock on irrigated pasture lands and for the production area of dairy farms, but until now, no waiver program regulated extensive grazing systems on nonirrigated lands or lands surrounding dairy facilities. The RWQCB's grazing waiver is required of dairies and ranches on parcels 50 acres or larger in the Tomales Bay Watershed.

The Tomales Bay Watershed implemented a Grazing Waiver Outreach Project in 2008 (Fig. 5). This project was designed to assist agricultural producers in complying with these new regulatory requirements. In conjunction with the other nine partnering organizations (Marin RCD, NRCS, RWQCB, Marin Agricultural Land Trust, Marin County Farm Bureau, Western United Dairymen, California Cattlemen Association, Point Reyes National Seashore, and Marin Organic), UCCE facilitated the coordination and implementation of a grazing waiver program to provide informational resources and to educate local ranchers. 


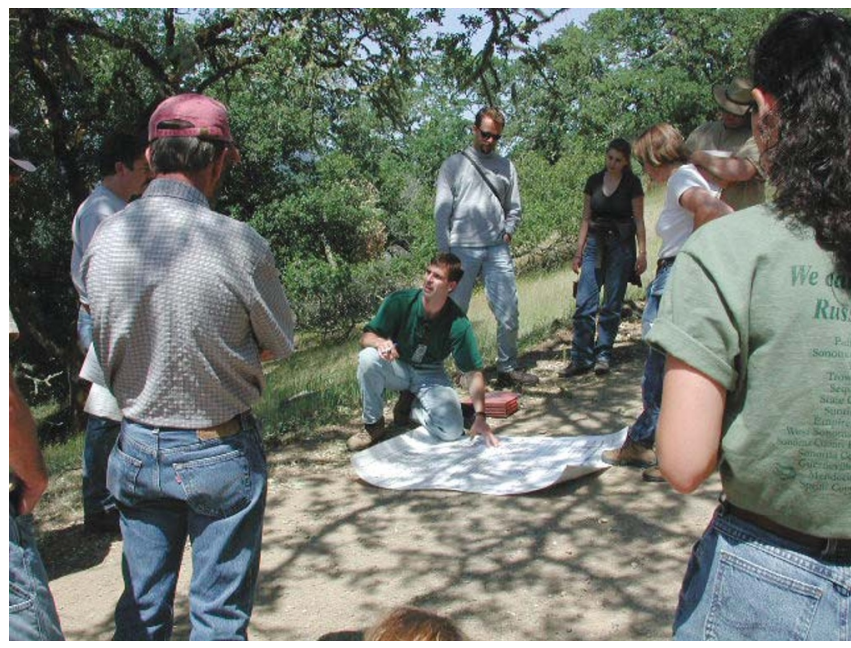

Figure 5. Grazing waiver outreach meeting in the Tomales Bay Watershed.

Following local workshops in November 2008, 85\% of grazing operators in the Tomales Bay Watershed were able to enter into the grazing waiver process. During the summer of 2009 the partnering organizations collaborated with UCCE to develop a planning process for completing the waiver requirements. Ranch plan templates were adapted from materials in the original short course described earlier in this paper. The plan is composed of required and optional components combined into one document entitled "Ranch Water Quality Plan, Compliance Monitoring and Annual Certification Templates." This was made available to grazing operators in a Ranch Planning Binder and online. Of the five required pages, the Annual Certification Form is very important and must be completed for the water board before November 15 every year. Over 158 Annual Certifications were submitted (>76\%) as of November 23, 2009. In addition, pasture and stream assessment questions need to be answered and future water quality projects need to be identified, unless the ranch in already in compliance. The ranch plan template is available on the internet at the RWQCB Web site for the Tomales Bay Watershed TMDL and Grazing Waiver: http://www.swrcb.ca.gov/rwqcb2/water issues/programs/TMDLs/tomalespathogens/FinalModelW QRanchPlan2009.pdf.

\section{Summary}

While the goal of this water quality education program was to help the owners and managers of range livestock operations to understand clean water issues and policies so that they could identify and assess pollution sources on the land they owned or managed, it has had numerous other benefits. Besides changing ranch practices, ranchers engaged the issue by starting watershed groups, becoming members of state advisory and policy boards, and supporting research into the fate and transport of sediment, pathogens, nutrients, and heat on California range and pasturelands. ${ }^{9-11}$ This program demonstrated how the land grant system can successfully engage public policy issues through teaching, research, and extension education. The local, regional, and statewide collaborations resulting from this program continue to work on water quality as they begin to focus on carbon sequestration and management for ecosystem services.

\section{References}

1. Gerstein, J. M., D. J. Lewis, K. Rodrigues, J. Harper, and J. Kabashima. 2006. State and federal approach to control of nonpoint sources of pollution. Davis, CA: University of California Division of Agriculture and Natural Resources. Publication No. 8203.7 p.

2. State Water Resources Control Board. 1995. California rangeland water quality management plan. Sacramento, CA: SWRCB. Division of Water Quality Nonpoint Source Program. $75 \mathrm{p}$.

3. Huntsinger, L., and L. P. Fortman. 1990. California's privately owned oak woodlands: owner, use and management. Journal of Range Management 50:423-430.

4. George, M., And L. Jolley. 1995. Management measures and practices. Davis, CA, USA: University of California. Fact Sheet No. 9, Rangeland Watershed Program. 5 p.

5. Bartolome, J. W., W. E. Frost, N. K. McDougald, AND M. Connor. 2002. California guidelines for residual dry matter (RDM) management on coastal and foothill annual rangelands. Oakland, CA: Division of Agriculture and Natural Resources, University of California. Publication No. 8092.8 p.

6. Lewis, D. J., K. W. Tate, J. M. Harper, and J. Price. 2001. Locating sediment sources on California's North Coast rangelands. California Agriculture 55(4):32-38.

7. Lewis, D. J., K. W. Tate, and J. M. Harper. 2000. Sediment delivery monitoring: a water quality tool for California Rangeland watersheds. Davis, CA: University of California Division of Agriculture and Natural Resources. Publication 8014. 14 p.

8. Larson, S., K. Smith, D. Lewis, J. Harper, and M. George. Evaluation of California's rangeland water quality education program. 2005. Rangeland Ecology \& Management 58:514-522.

9. Tate, K. W., D. L. Lancaster, and D. F. Lile. 2007. Assessment of thermal stratification within stream pools as a mechanism to provide refugia for native trout in hot, arid rangelands. Environmental Monitoring and Assessment 124:289-300.

10. Lewis, D. J., M. J. Singer, R. A. Dahlgren, and K. W. TATE. 2006. Nitrate and sediment fluxes from a California rangeland watershed. Journal of Environmental Quality 35:22022211.

11. Tate, K. W., E. R. Atwill, J. W. Bartolome, and G. A. NAdER. 2006. Significant $E$. coli attenuation by vegetative buffers on annual grasslands. Journal of Environmental Quality 35:795-805.

Authors are Extension Rangeland Management Specialist, Dept of Plant Sciences, University of California, Davis, Davis, CA 95616, USA, mrgeorge@ucdavis.edu (George); Livestock and Natural Resources Advisor, Marin-Sonoma Counties, Santa Rosa, CA 95403, USA (Larson-Praplan); Livestock and Natural Resources Advisor, Mendocino County, Ukiah, CA 95482, USA (Harper); Watershed Advisor, Marin-Sonoma Counties, Novato, CA 94947, USA (Lewis); and Staff Research Associate, Sonoma County, Santa Rosa, CA 95403, USA (Lennox). 